\title{
A NEW LYCASTE (ORCHIDACEAE: MAXILLARIINAE) FROM COSTA RICA
}

\author{
DIEGO BOGARÍN \\ Jardín Botánico Lankester, Universidad de Costa Rica. P.O. Box 1031-7050 Cartago, Costa Rica, A.C.; \\ Centro de Investigación en Orquídeas de los Andes “Ángel Andreetta”, Universidad Alfredo Pérez Guerrero, \\ Extensión Gualaceo, Ecuador. \\ dbogarin@cariari.ucr.ac.cr
}

\begin{abstract}
Lycaste bruncana from Costa Rica is described and illustrated. This species is sister to L. tricol$o r$, its closest relative, from which is easily distinguished by the lip shape, with a narrow isthmus and spathulate midlobe, the lanate to lanulose infrastigmatic surface, the pollinarium with a longer stipe, the subrectangular pollinia and the tomentose anther cap. However, among Costa Rican species of Lycaste, the most remarkable character of $L$. bruncana is the twisted column, which may be indicative of a reproductive barrier. Information related to biogeography, distribution, morphology, molecular data and pollination is provided and discussed.
\end{abstract}

RESUMEN: Se describe e ilustra Lycaste bruncana de Costa Rica. Esta especie es hermana de L. tricolor, su pariente más cercana, de la cual se distingue fácilmente por la forma del labelo, con un istmo estrecho y el lóbulo medio espatulado, la superficie infraestigmática lanada a lanulosa, el polinario con un estípite más largo, los polinios subrectangulares y la capa de la antera tomentosa. Sin embargo, entre las especies costarricenses de Lycaste, el carácter más notable de L. bruncana es la columna torcida, la cual puede ser indicativa de una barrera reproductiva. Se proporciona y discute información relacionada con biogeografía, distribución, morfología, datos moleculares y polinización.

KEY WoRDS: Orchidaceae, Lycaste, Lycaste bruncana, new species, Costa Rica, DNA barcoding, orchid pollination.

After its introduction to Europe by the Spanish expedition to Peru and Chile by H. Ruiz and J. Pavón in the eigthteeth century, and the description of the first specimens referable to the genus Lycaste Lindl., by E. Poeppig \& L. Endlicher in Nova Genera and Species Plantarum (1833-1835), plants of this genus became one of the most famous and popular orchids in cultivation (Oakeley 1993). The genus was created by J. Lindley in 1843 based on morphologic characters, separating this group of orchids from the genus Maxillaria Ruiz \& Pav. Molecular studies used to assess the phylogenetic relationships between the species of Lycaste and Anguloa Ruiz \& Pav. showed that the mainly South American group of Lycaste section Fimbriatae Fowlie, deserves a generic status (Ryan et al. 2000). Ryan \& Oakeley (2003) proposed the genus Ida A. Ryan \& Oakeley to include the former group, reducing Lycaste to species mainly Mesoamerican in distribution.
In spite of this generic separation, both genera have been recognized for their beauty and horticultural value. Species pertaining to groups of orchids popular in cultivation are often well known taxonomically, and it is not surprising that in his Essential Guide of Lycaste species, Oakeley (1993) opened his introduction saying "if it is not in here it has not been described". However, when a good taxonomic system is developed in countries rich in plants species, supported by an efficient system of information, taxonomic novelties often appear also in previously monographed and botanically well-sampled genera (Pupulin \& Bogarín 2005, Dressler \& Pupulin 2006, Pupulin 2007).

Hereafter, Lycaste bruncana is presented as a new species to the science.

\section{Lycaste bruncana Bogarín, sp. nov.}

Type: Costa Rica. Puntarenas: Golfito, Golfito, Esquinas, La Gamba, Bosque de Los Austriacos, 
Tropenstation La Gamba, 8 ${ }^{\circ} 42^{\prime} 40^{\prime \prime} \mathrm{N} 83^{\circ} 13^{\prime} 00^{\prime \prime} \mathrm{W}$, 100-400 m, 3-4 Julio 2004, M. Blanco 2610 \& E. Serrano, floreció en cultivo en el Jardín Botánico Lankester, 19 Julio 2007, D. Bogarín 3987 (holotype: CR; isotype: JBL-spirit). FIG. 1.

Lycaste tricolori (Klotzsch.) Rchb.f. affinis, a qua lobulo medio labelli spathulato, isthmo angustiore longioreque, anthera tomentosa, superficie infrastigmatica lanato-lanulosa, stipite pollinarii longiore et apice columnae leviter torto imprimis differt.

Plant epiphytic, cespitose, up to $60 \mathrm{~cm}$ tall. Roots slender, up to $3 \mathrm{~mm}$ in diameter, covered by absorptive hairs. Pseudobulbs 5-7 x 3-4.5 cm, ovoid, sulcate, ancipitous, with inconspicuous spines when deciduous and subtended by scarious sheats. Leaves two (rarely three) apical leaves and 2-3 lateral leaves adpressed to each young pseudobulb, articulate, persistent during the blooming period, deciduous with age. Leaf blade petiolate, $5.5 \times 51 \mathrm{~cm}$, plicate, obovate, acute to acuminate, with 5 conspicuous veins. Inflorescence, one to six, pedunculate, to $9 \mathrm{~cm}$ long, 1-flowered, concealed by 2-3 persistent, imbricate, ovate, acute, bracts, flowering usually with a new growth. Floral bract 2.5-3 x 2-2.5 cm, ovate, acute, enclosing the ovary. Ovary cylindrical, sulcate, smooth, $1.7 \mathrm{~cm}$ long, $3.5 \mathrm{~mm}$ in diameter. Flowers showy, from 1 to several open at the same time, sepals pale green to pinkish, petals white, spotted with pink, lip white with purple dots around the callus and pink dots in the midlobe. Sepals equal, rectangular-obovate, acute, $4.5 \mathrm{x}$ $1.7 \mathrm{~cm}$, basally tomentulose, margin entire, straight in natural position. Petals ovate, acute, slightly crenate at apex, 3.5-4.2 x 1.5-1.7 cm, recurved in natural position. Lip three-lobed, $2.7 \times 1.2 \mathrm{~cm}$, attached to the column foot, with a rectangular thick, emarginate callus up to $1.3 \mathrm{~cm}$ long, lateral lobes rectangular, obtuse, thick, perpendicular to the callus, $1.2 \times 0.5 \mathrm{~cm}$, midlobe spathulate, thin, the isthmus narrow, emarginate, erose at apex, $1.5-1.7 \times 0.3 \mathrm{~cm}$. Column with a purplespotted foot, twisted to the left, basally tomentulose, silky at apex, infrastigmatic surface lanulose, the stigma ventral; anther apical, up to 2.5 long. Pollinarium $6 \mathrm{~mm}$ long, with four pollinia, two rectangular-ovoid and two subequal, smaller; stipe $3.5 \mathrm{~mm}$ long. Anther cap cucullate, tomentose. Capsule not seen.

Paratypes: San José: Pérez Zeledón, Pejibaye, Fila
Costeña, Zapote de Pejivalle, 9 ${ }^{\circ} 07^{\prime} 37.3$ ”N $83^{\circ} 33^{\prime} 22.7^{\prime \prime} \mathrm{W}, 740-810 \mathrm{~m}$, along the margins of a small river, remnants of primary forest and secondary forest, 10 December 2000, F. Pupulin 2654, D. Castelfranco \& J. Cambronero (JBL-Spirit). Pérez Zeledón, San Isidro de El General, carretera a Dominical, Fila Tinamastes, La Alfombra,

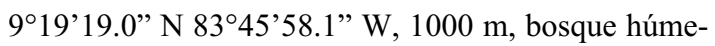
do premontano, bosque secundario alterado y árboles a orillas de la carretera, 23 Octubre 2005, A. Karremans 1076, J. Cambronero, R.L. Dressler, R. Gómez, D. Bogarín, F. Pupulin, A. \& S. Rambelli (JBL-Spirit). Puntarenas: Aguirre, Naranjillo, road between Quepos and San Marcos de Tarrazú, 750 m, $9^{\circ} 33^{\prime} 01^{\prime \prime} \mathrm{N} 84^{\circ} 05^{\prime} 01^{\prime \prime} \mathrm{W}$, wet premontane transition to lower montane forest remnants of primary and secondary mature vegetation, 1 January 2001, F. Pupulin 2780, D. Castelfranco \& E. Salas (JBL-Spirit). Golfito, Golfito, Esquinas, La Gamba, Bosque de Los Austriacos, Tropenstation La Gamba, $8^{\circ} 42^{\prime} 40^{\prime \prime} \mathrm{N}$ $83^{\circ} 13^{\prime} 00^{\prime \prime} \mathrm{W}, 100-400 \mathrm{~m}, 3-4$ Julio 2004, M. Blanco 2610 \& E. Serrano (JBL-Spirit).

Distribution: known only from the southern Pacific watershed of Cordillera de Talamanca and Cordillera Costeña, Costa Rica, between 700 and 1000 m of elevation. Southernmost collections suggest that this species may occur around the Chiriquí river valley in Panama, which represents the southernmost extension of the Cordillera Costeña. Plants of L. tricolor have similar elevation range but are restricted to the Atlantic slopes of Costa Rica and Panama.

Etymology: From the emblematic name "Brunca", which comes from the indigenous people who live in the southern Pacific lands of Cordillera de Talamanca. Brunca also names the Región Brunca, one of the socioeconomic regions of Costa Rica that occupies most of the distribution range of this species.

HaBitat: Plants of this species grew epiphytically in primary and secondary vegetation in premontane rain forest, tropical wet forest-premontane belt transition, tropical moist forest-premontane belt transition and tropical wet forest. All these life zones strictly correspond to the southern Pacific watershed of Cordillera de Talamanca and Fila (Cordillera) Costeña. 

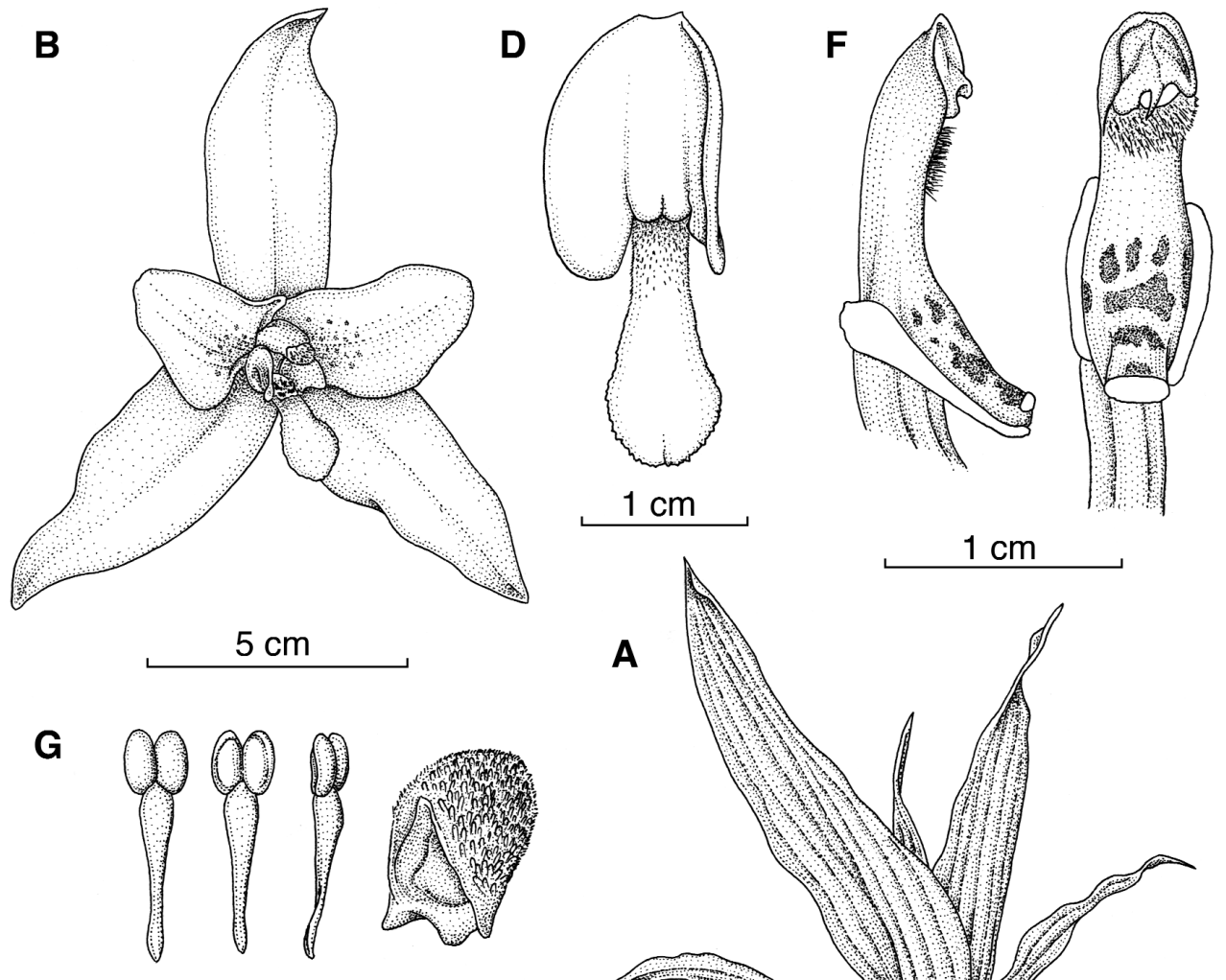

A
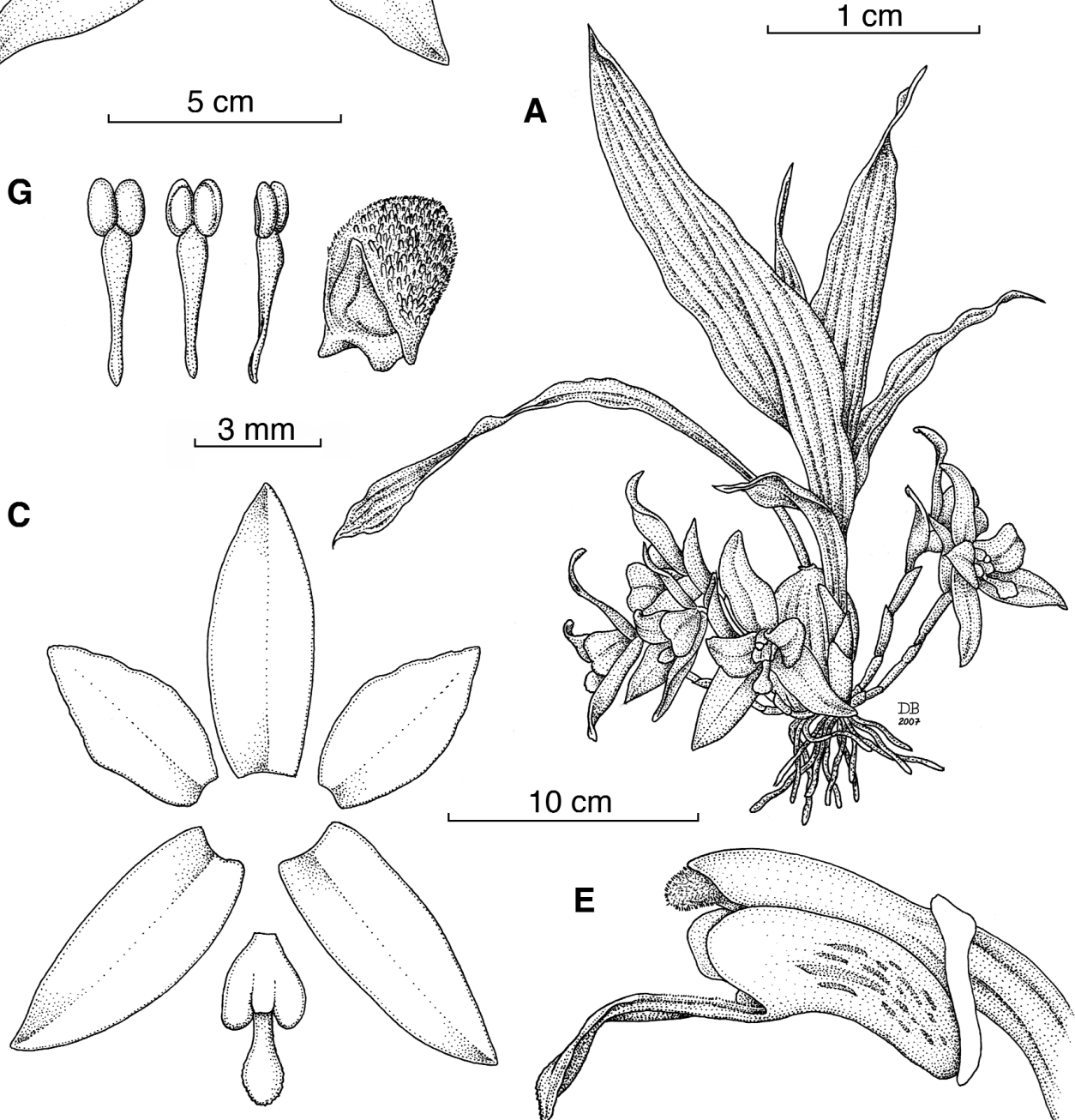

$5 \mathrm{~cm}$

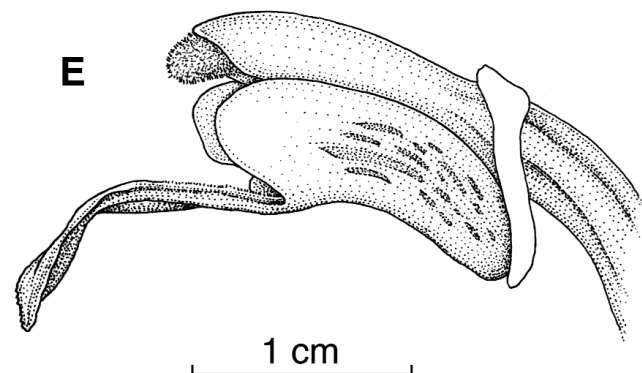

FiguRe 1. A-G. Lycaste bruncana Bogarín. A. Habit. B. Flower in natural position. C. Dissected perianth. D. Lip. E. Column and lip, lateral view. F. Column. lateral and frontal view. G. Pollinarium (front view, dorsal view and lateral view) and anther cap. Drawn from the holotype by Diego Bogarín. 
CONSERVATION STATUS: The species has been recorded in protected areas. The type collection comes from The Field Station La Gamba, situated in the south of Puntarenas province, in Golfito. It constitutes the first record for this research center, where no Lycaste species were previously recorded (Weissenhofer et al. 2001). Biogeographical similitudes and proximity between this area, Piedras Blancas National Park and Corcovado National Park, also suggest that L. bruncana may well occur in those protected areas. An unvouchered specimen in cultivation (J. Clarke 314) from Boracayán Wildlife Refuge around Fila Alivio in the upper Río Barucito basin, Cordillera Costeña, is also recorded from a protected area. Apparently, this species is not rare and some specimens were collected in disturbed areas. This species should not be regarded as endangered.

Phenology: Plants in cultivation flower from May to July. Some plants can extend the flowering season up to October.

This species is closely related to L. tricolor, a widespread species from the Atlantic lands of Costa Rica and Panama. In a survey of Lycaste species in Costa Rica, Horich (1977) cited several specimens of L. tricolor from the Atlantic side of both Tilarán and Central Volcanic chains. Also, he stated that L. tricolor has no close affinities or intermediate relatives in the genus. It seems that he never had access to material from the Pacifc watershed of Cordillera de Talamanca (Horich1966). Oakeley $(199$ 1, 1993) discussed L. tricolor as a tiny pink to white flower species with the lip provided with a marked isthmus, and a projecting discoid callus. All geographic data and pictures presented in his work are correctly attributed to L. tricolor.

The only record that may eventually correspond to a first collection of L. bruncana is the "small dwarf race" (Fowlie 1970: 7) of L. tricolor that was apparently collected in San Vito de Java, a region that is included in the current distribution area of L. bruncana. However, no herbarium specimens or vouchers of this species were apparently prepared by the author (Fowlie 1970). Recent treatments of Costa Rican and Mesoamerican orchidaceae do not mention any collections of Lycaste tricolor from the Pacific watershed of Cordillera de Talamanca (Dressler 2003, Ossenbach et al. 2007).
According to Fowlie (1970) and following his classification of the genus, both species should be placed in the section Deciduosae subsection Paradeciduosae Fowlie. Although the similarities between the two species (i.e., the three-lobed lip, the deciduous pseudobulbs without conspicuous spines, the similar size of the plant, and the gross flower morphology) could have confused taxonomists in the past, Lycaste borucana may be easily distinguished on the basis of a consistent set of morphological features.

Lycaste bruncana is distinguished from $L$. tricolor by the lip shape with a narrow isthmus and spathulate midlobe (vs. ovate), the lanate to lanulose infrastigmatic surface (vs. smooth), the pollinarium with a longer stipe (up to $3.5 \mathrm{~mm}$ long), the subrectangular pollinia (vs. ovoid) and the tomentose anther cap (vs. smooth) (Figs. 2-5). However, the most remarkable character to recognize L. bruncana is the twisted column, which may be indicative of a reproductive barrier with respect of its relative (Fig. 5). Among the species of Costa Rican Lycaste, this is the only species that presents a twisted column (Dressler 2003).

All the former characters are diagnostic and show no variation among individuals. The length of lip is variable, ranging from 1.5 to $2.7 \mathrm{~cm}$, however the midlobe is spathulate in all collections studied (Fig. 2). Small plants cultivated at Lankester Botanical Garden produced smaller flowers than the robust plants. The number of flowers produced by a plant varies from one to six in each growth and it depends

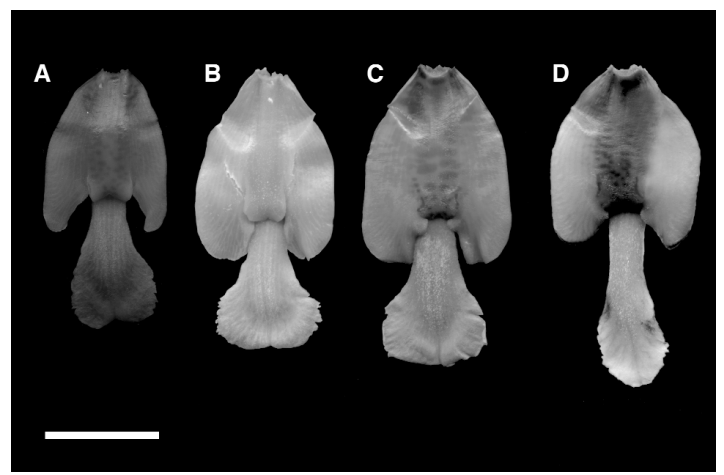

FIGURE 2. Variation in the lip length among individuals of L. bruncana. A. from A. Karremans 1076. B. from $F$. Pupulin 2654. C. from $F$. Pupulin 2780. D. from $D$. Bogarín 3987. All vouchers in JBL-spirit collection. Scale bar $=1 \mathrm{~cm}$. 


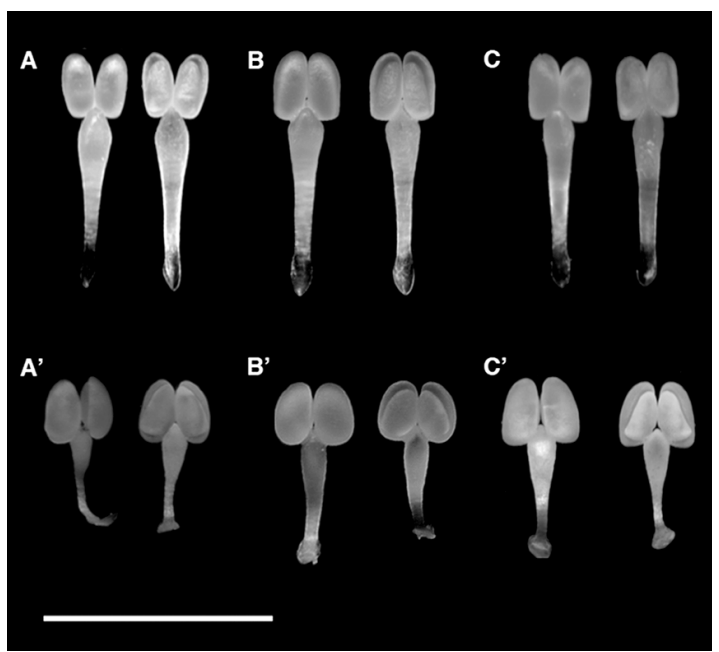

FIgURE 3. Comparison of the pollinarium shape between L. bruncana and L. tricolor. A-C, L. bruncana. A. from D. Bogarín 3987. B. from F. Pupulin 2780. C. from $A$. Karremans 1076. A'-C' L. tricolor. A'. from $J B L$ 02995. B'. from D. Bogarín 733. C'. from $J B L-06408$. All vouchers in JBL-pollinaria collection. Scale bar $=5$ $\mathrm{mm}$.

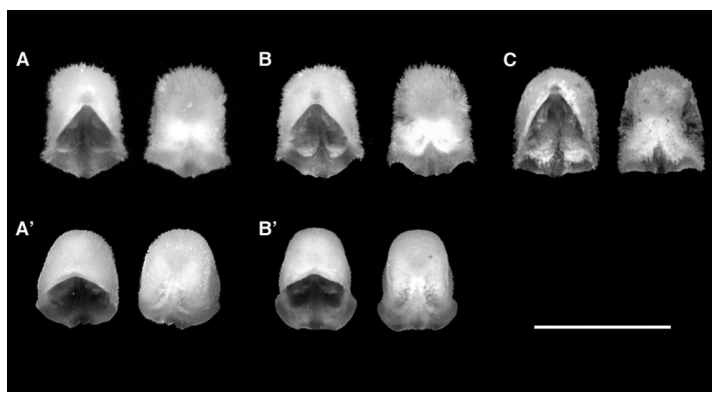

FIgURE 4. Comparison between anther cap shape in $L$. bruncana and L. tricolor. A-C. L. bruncana. A. from $D$. Bogarin 3987. B. from F. Pupulin 2780. C. from $A$. Karremans 1076. A'-B' L. tricolor. A'. from $D$. Bogarín 733. B'. from JBL-06408. All vouchers in JBLspirit collection. Scale bar $=5 \mathrm{~mm}$.

on both the robustness of the plant and the number of pseudobulbs present. Flower coloration is rather constant, with concolor sepals and petals with pink spots, however, slightly paler flowers have been observed among the different collections. The distinctive column, twisted to the left, showed no variation among individuals and the individual flowers of the same plant. All the studied flowers showed twisted columns.

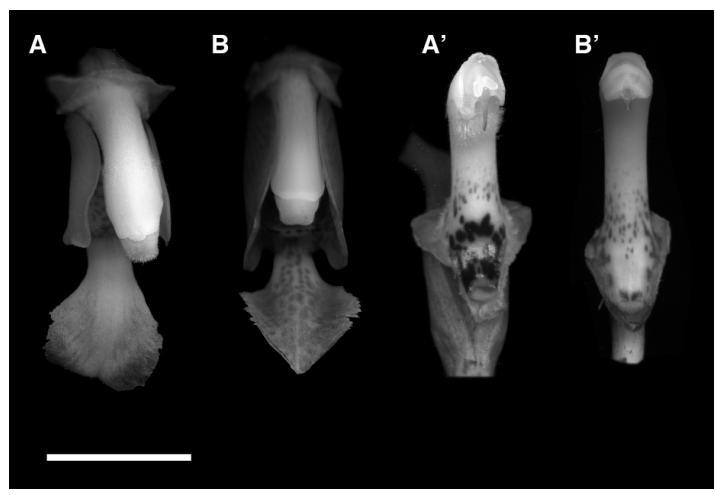

FiguRE 5. Comparison of the column shape in L. bruncana and L. tricolor. A-A'. L. bruncana. A. Upper view, showing the twisted column. A'. Frontal view, showing the twistened column and the lanulose infraestigmatic surface. From A. Karremans 1076 (JBL-spirit). B-B'. Lycaste tricolor. B. Upper view, showing the straight column. B'. Frontal view, showing the straight column and smooth infraestigmatic surface. From D. Bogarin 733 (JBL-spirit). Scale bar $=1 \mathrm{~cm}$.

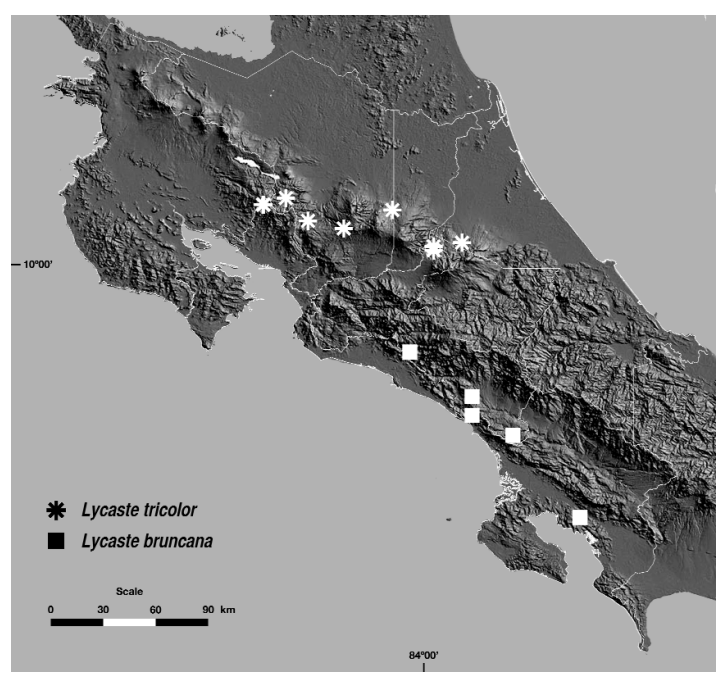

MAP 1. Distribution of L. bruncana and L. tricolor.

After the submission of this paper, an anonymous reviewer suggested commenting on two names not validly published that supposedly have been used for this species. Although the International Code of Botanical Nomenclature (McNeill et al. 2006) expressly recommends (Recomm. 34A) that authors should avoid mentioning previously unpublished names, I found two citations of the name Lycaste crystallina, both of them nomina nuda, with differ- 
ent authorship. Lycaste crystallina M.A. Dix, nom. nud., (Missouri Botanical Garden 2007) is ostensibly based on Blanco 2610, designated here as a paratype of L. bruncana. The other citation, as Lycaste crystallina Wubben ex H.F. Oakeley, nom. nud., was found at Bibliorchidea (Swiss Orchid Fundation 2007) and refers to a recent article by Oakeley (2007) where the author anticipated the publication of L. crystallina as a new species, however it does not constitute a valid name (see Code, art. 34.1). No information at all was retreived about the other unpublished name suggested by the anonymous reviewer.

BIOGEOGRAPHY - According to the locality data available for both species, they are geographically separated (Map 1). All the collections of L. tricolor correspond to the Atlantic watershed of the Cordillera de Tilarán, the Central Volcanic chain and the Talamanca range. On the other side, all collections of L. bruncana come from the Pacific watershed of the Cordillera de Talamanca and the Cordillera Costeña. Analogous examples of sister orchid species in the Atlantic and Pacific regions of Talamanca range have been documented in the genus Kefersteinia (Pupulin 2001). These examples support the role of the Cordillera de Talamanca as a geographic isolation barrier, where these sister species have evolved separately.

Though the Cordillera Costeña and nearby areas have been explored botanically since several years ago, new species have been recently revealed from the region (Gómez-Laurito 2006). A well defined floristic pattern is present in Cordillera Costeña and its neighboring areas. Its geographic position, geologic history and the inherent climatological characteristics given by the rain patterns and humid winds that come from the Pacific, make this area rich in endemisms.

Molecular DATA - Sequences using matK chloroplast region obtained to assess the candidate barcode for flowering plants support the clustering of the accessions of $L$. tricolor. This species is placed separately from the accessions of $L$. bruncana. The plant of $L$. bruncana from which the type specimen was prepared (Gene Bank accession EU214496) was used to obtain the matK sequence analysed for barcoding pourposes (Lahaye et al. in prep). In the former work, authors concluded that L. borucana (cited there as Lycaste cf. tricolor) is a cryptic species supported by DNA barcoding. Lycaste bruncana does not cluster with the three accessions of L. tricolor assessed in the study. In conclusion, molecular evidence supports the identity of $L$. bruncana, as a species distinct from its relative, L. tricolor.

Pollination ECOlOgy - Lycaste is a typical bee-pollinated flower (Roubik \& Hanson 2004). The distinctive twisted column present in L. bruncana might also be indicative of a reproductive barrier whereby L. bruncana would deposit the pollinarium on the shoulder of the pollinating bees and $L$. tricolor, with its straight column, would deposit the pollinarium on the scutellum. Pollination studies in orchids around Golfito area did not reveal any potential bee pollinator of Lycaste species (Lobo \& Bolaños 2005). More observations and comparisons between pollination biology of both species may confirm the reproductive isolation barrier inferred by flower morphology. This acquires special interest since the two species overlap their flowering season so, differences in both, flower morphology and the way in which these species use the pollinator to carry the pollinarium, ensure a reproductive isolation. This isolation barrier supports the distinction between L. bruncana and L. tricolor.

AcKnowledgements. I want to thank Franco Pupulin and Robert L. Dressler for their invaluable support and their useful comments on the paper. To my colleagues José Daniel Zúñiga and Mario Blanco who kindly provided useful information. The scientific services of Costa Rican Ministery of Environment and Energy (MINAE) and its National System of Conservation Areas (SINAC) for issuing the collecting permits under which wild species treated in this study were collected. The staff of Tropenstation La Gamba for granting access to the installations and for the research facilities. The staff of Jodrell Laboratory of Royal Botanic Gardens, Kew, specially Guillaume Gigot, Martyn Powell and Vincent Savolainen, for their help with the DNA barcoding work and to Renaud Lahaye who analysed the molecular data. The UK Darwin Initiative for the Survival of Species sponsored field work activities under the project "Conservation and Monitoring of MesoAmerican Orchids" (Ref.14001). 


\section{LiteratuRe Cited}

Dressler, R. L. 2003. Lycaste. Pp. 262-264 in: B.E. Hammel, M. H. Grayum, C. Herrera \& N. Zamora (eds.). Manual de las Plantas de Costa Rica Vol III. Orchidaceae-Zingiberaceae. Monogr. Syst. Bot. Missouri Bot. Gard. 93.

Dressler, R. L \& F. Pupulin. 2006. The carmine Trichopilias of Central America: few but badly confused. Orchids 75(3): 212-219.

Fowlie, J.A. 1970. The genus Lycaste. Azul Quinta Press. $90 \mathrm{p}$.

Gómez-Laurito, J. 2006. Una nueva especie de Justicia (Acanthaceae) del sur de Costa Rica. Lankesteriana 6 (3) : 155-156.

Horich, C.K. 1966. Lycaste brevispatha und Lycaste tricolor. Die Orchidee 2: 74-77.

Horich, C. K. 1977. The Costa Rican Lycaste Species. Orchid Digest. 41(4): 125-130.

Lobo, J \& F. Bolaños. 2005. Historial natural de Golfito. Editorial INBio, Santo Domingo de Heredia, Costa Rica. 264 pp.

McNeill, J., F.R. Barrie, H.M. Burdet, V. Demoulin, D.L. Hawksworth, K. Marhold, D.H. Nicolson. J. Prado, P.C. Silva, J.E. Skog, J.H. Wiersema \& N.J. Turland. 2006. International Code of Botanical Nomenclature (Vienna Code). Regnum Veg. 146. A.R.G. Gantner Verlag KG.

Missouri Botanical Garden. 2007. TROPICOS Database. http://mobot.mobot.org/cgi-bin/search_vast

Oakeley, H. 1993. Lycaste Species. The essential guide. Vigo Press. 34 p.

Oakeley, H. 1991. A survey of Lycastes 4: Lycaste brevispatha to Lyc. xytriophora. Amer. Orchid Soc. Bull. 60: 634-644.

Oakeley, H. 2007. A new infrageneric clsssification of
Lycaste (Lindl.) and a checklist of species for the genus Lycaste. Orchid Digest 71: 196-208.

Ossenbach, C., F. Pupulin \& R.L. Dressler. 2007. Orchids of the Central American Isthmus. Checklist and Conservation Status. Editorial 25 de Mayo, San José, Costa Rica. 243 p.

Pupulin, F. 2001. Contributions to a reassessment of Costa Rican Zygopetalinae (Orchidaceae). The genus Kefersteinia Rchb.f. Ann. Naturhist. Mus. Wien. Serie B 3: 525-555.

Pupulin, F. 2007. Epidendra, the botanical databases of Jardín Botánico Lankester at the University of Costa Rica. Lankesteriana 7(1-2): 178-180.

Pupulin, F. \& D. Bogarín. 2005. The genus Brassia in Costa Rica: A survey of four species and a new species. Orchids 74 : 202-207.

Roubik, D.W \& P.E. Hanson. 2004. Abejas de orquídeas de la América tropical: Biología y guía de campo. Orchid bees of tropical America: Biology and field guide. Editorial INBio, Santo Domingo de Heredia, C.R. 370 p.

Ryan, A., W. M. Whitten, M. A. Johnson \& M. W. Chase. 2000. A phylogenetic assessment of Lycaste and Anguloa (Orchidaceae: Maxillarieae). Lindleyana 15:33-45.

Ryan, A. \& H. Oakeley. 2003. Ida A. Ryan and Oakeley, a new genus, based on Lycaste section Fimbriatae Fowlie (Orchidaceae, tribe Cymbideae, subtribe Lycastinae). Orchid Dig. 67(1): 8-10.

Swiss Orchid Foundation. 2007. Bibliorchidea. http://www.orchid.unibas.ch/bibliorchidea.index.php

Weissenhofer, A., H. Werner, A. Weber, G. Zimmermann \& N. Zamora. 2001. An introductory Field Guide to the flowering plants of the Corcovado and Piedras Blancas National Park (Regenwald der Österreicher). OÖ Landesmuseum Linz, Biologiezentrum, JohannWilhelm Kleinstraße. 464 p. 
LANKESTERIANA 